\title{
PENINGKATAN KEMAMPUAN PEMECAHAN MASALAH MATEMATIS SISWA SMP MELALUI PEMBELAJARAN ACCELERATED LEARNING
}

\author{
R. H. Yanti Silitonga \\ Program Studi Pendidikan Matematika Fakultas Keguruan dan Ilmu Pendidikan, Universitas Pattimura \\ Jalan Ir. M. Putuhena Unpatti, Poka, Ambon, Indonesia \\ *Email korespondensi: rhyanti_silitonga@yahoo.com
}

\begin{abstract}
ABSTRAK
Penelitian ini bertujuan untuk mengetahui peningkatan kemampuan pemecahan masalah matematis siswa dengan pembelajaran accelerated learning. Penelitian ini berbentuk kuasi eksperimen memiliki desain kelas kontrol pretes-postes. Sampel penelitian sebanyak 66 orang siswa SMP Swasta di Bandung. Kelas eksperimen diberikan pembelajaran accelerated learning sementara kelas kontrol memperoleh pembelajaran ekspositori. Data penelitian didapat dari tes kemampuan pemecahan masalah matematis. Dari analisis data perbedaan rata-rata menggunakan uji Mann-Whitney diperoleh peningkatan kemampuan pemecahan masalah matematis siswa yang mendapat pembelajaran accelerated learning lebih tinggi secara signifikan daripada siswa yang diberikan pembelajaran ekspositori.
\end{abstract}

Kata kunci: accelerated learning, pemecahan masalah matematis.

\begin{abstract}
This research aims to determine enhancing students mathematical problem solving through the implementation of accelerated learning. This study is a quasi experiment with control group pretestpostest design. The study had been conducted with 66 students of SMP in Bandung. The experiment group obtained accelerated learning and control group obtained expository learning. Data was collected from students trough mathematical problem solving test. Data was analyzed using average of difference test that was Mann-Whitney and showed that the enhancement of mathematical problem solving ability of students who have obtained accelerated learning are better than students who have obtained expository learning.
\end{abstract}

Keywords: accelerated learning, mathematical problem solving.

\section{PENDAHULUAN}

Siswa memiliki kemampuan dalam melakukan pemecahan masalah matematis adalah suatu keharusan. Hal ini dikarenakan dalam kesehariannnya siswa dihadapkan dengan banyak 
permasalahan dan siswa dituntut untuk memiliki kemampuan untuk menyelesaikan masalah tersebut. Siswa yang dapat menyelesaikan permasalahan yang dihadapi dalam kesehariannya kemungkinan lebih siap menghadapi segala kemungkinan permasalahan yang muncul di dunia kerja (Suryadi, 2005). Kemampuan pemecahan masalah matematis tercantum pada tujuan pembelajaran matematika sebagai salah satu kemampuan matematis yang harus dimiliki siswa semakin menunjukkan bahwa kemampuan pemecahan masalah sangat penting dan bahkan merupakan jantung dari matematika (Branca, 1980:3-7). Polya (1985) mengungkapkan bahwa siswa dikatakan memiliki kemampuan pemecahan masalah matematis apabila siswa mampu memamahami masalah kemudian merancang model matematika untuk masalah tersebut kemudian melakukan penyelesaian model matematika yang telah dibuat serta melakukan penaksiran dari hasil penyelesaian yang siswa peroleh.

Upaya agar siswa mengalami peningkatan kemampuan dalam pemecahan masalah matematis wajib dilakukan. Metode belajar yang digunakan dalam pembelajaran matematika akan mempengaruhi peningkatan kemampuan pemecahan masalah matematis. Metode pembelajaran yang tepat yaitu pembelajaran yang membuat siswa aktif karena pembelajarannya menyenangkan. Kemudian siswa mampu memahami materi yang disampaikan dan menguasai materi tersebut. Alternatif pembelajaran yang membuat siswa untuk aktif sehingga mencapai percepatan belajar adalah pembelajaran accelerated learning. Dalam pembelajaran accelerated learning, percepatan belajar dapat terjadi karena siswa diberikan tugas belajar di rumah untuk mempelajari materi pelajaran selanjutnya, memberi kesempatan untuk mengajukan pertanyaan, memberikan jawaban ketika ada yang bertanya, memberi penjelasan mengapa menjawab seperti itu, terjadi interaksi, diskusi dan kerjasama dengan siswa lain (Putra, 2012:9).

Accelerated learning terdiri dari enam langkah yang dikenal dengan kata MASTER yaitu Mind, Acquire, Seacrh out, Trigger, Exhibit, dan Refleksi. Pada langkah Mind yaitu keadaan pikiran siswa dimana siswa diberikan motivasi supaya siap belajar. Acquire yaitu memperoleh informasi dari guru dimana informasi yang diberikan adalah informasi yang mendasar bertujuan untuk mendorong siswa mencari informasi lebih lanjut. Seacrh out atau menyelidiki makna dimana siswa diberikan pertanyaan yang memicu siswa untuk memecahkan masalah. Langkah trigger yaitu memicu memori dimana siswa mengulang materi yang sudah dipelajari. Exhibit yaitu memamerkan apa yang telah diketahui dimana 
siswa mempresentasikan hasil pekerjaannya secara berkelompok. Refleksi yaitu merefleksikan cara belajar dimana siswa mengevaluasi cara dan hasil belajar lalu merencanakan cara belajar (Rose dan Nicholl, 2009).

Secara rinci rumusan penelitian ini adalah untuk mengetahui peningkatan kemampuan pemecahan masalah matematis siswa pada kelas yang mendapatkan pembelajaran accelerated learning lebih tinggi secara signifikan daripada siswa pada kelas yang mendapatkan pembelajaran ekspositori.

\section{METODE PENELITIAN}

Penelitian eksperimen ini dilaksanakan dengan desain kelas kontrol pretes-postes dimana terdapat dua kelas. Satu kelas dijadikan kelas kontrol sedangkan yang lain menjadi kelas eksperimen (Ruseffendi, 2005). Kelas kontrol mendapatkan pembelajaran ekspositori sementara kelas eksperimen mendapat pembelajaran accelerated learning. Lebih lanjut, penelitian ini untuk melihat perbedaan kemampuan pemecahan masalah matematis yang dimiliki oleh siswa pada kelas kontrol maupun eksperimen. Untuk menentukan kelas yang menjadi kelas kontrol dan kelas yang dijadikan kelas eksperimen maka dilakukan pengundian kelas. Kelas eksperimen dan kelas kontrol masing-masing mendapatkan pretes (O), lalu kelas eksperimen mendapat pembelajaran accelerated learning dan kelas kontrol mendapat pembelajaran ekspositori. Setelah itu, kedua kelas diberikan postes (O). Gambar desain penelitian yang digunakan adalah sebagai berikut:

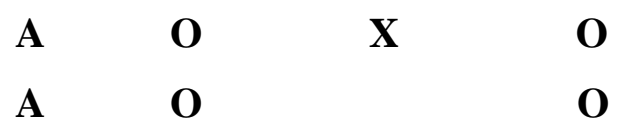

Keterangan:

$\mathrm{A}=$ Pemilihan kelas dilakukan dengan acak

$\mathrm{X}=$ Perlakuan pembelajaran accelerated learning

$\mathrm{O}=$ Tes awal/Pretes dan Tes akhir/Postes

Penelitian eksperimen ini memiliki populasi yaitu seluruh siswa kelas VII di sebuah SMP Swasta Bandung yang terdiri dari enam kelas yakni kelas VIIA, VIIB, VIIC, VIID, VIIE dan VIIF. Pengambilan sampel penelitian dilakukan dengan acak. Dari pemilihan sampel tersebut, maka diperoleh kelas eksperimen adalah kelas VIIA sedangkan kelas kontrol adalah kelas VIIB. Kelas VIIA dan kelas VIIB memiliki jumlah yang sama yaitu 33 siswa. Hasil pretes dan postes kemampuan pemecahan masalah matematis siswa dilakukan analisa untuk 
melihat seberapa besar peningkatan kemampuan mecahan masalah matematis siswa dari setiap kelas. Penghitungan besarnya peningkatan yang diperoleh masing-masing kelas menggunakan gain ternomalisasi dengan rumusnya adalah :

$$
g=\frac{\text { skor postes }- \text { skor pretes }}{\text { skor maksimum }- \text { skor pretes }}
$$

Adapun level indeks gain ternomalisasi menurut Hake (1999) terdiri dari tiga level yaitu tinggi, sedang, dan Rendah. Batas-batas dari setiap level indeks gain disajikan dalam Tabel 1 berikut.

Tabel 1. Kriteria Indeks Gain Ternormalisasi

\begin{tabular}{cc}
\hline Indeks Gain Ternomalisasi & Kriteria \\
\hline $\mathrm{g}>0,70$ & Tinggi \\
$0,30<\mathrm{g} \leq 0,70$ & Sedang \\
$\mathrm{g} \leq 0,30$ & Rendah
\end{tabular}

Untuk menguji hipotesis terlebih dahulu dilakukan pengujian syarat statistik yakni uji normalitas dan uji homogenitas. Uji normalitas dilakukan untuk mengetahui apakah yang data yang diperoleh berdistribusi normal atau tidak. Sedangkan uji homogenitas untuk melihat variansi setiap kelompok data sama atau tidak. Selanjutnya pengujian data dengan menggunakan uji-t untuk data memiliki distribusi normal serta mempunyai variansi homogen. Uji Mann-Whitney dilakukan apabila paling sedikit satu kelas berdistribusi tidak normal.

\section{HASIL DAN PEMBAHASAN}

Pemberian skor berdasarkan kriteria skor tes kemampuan pemecahan masalah matematis diadaptasi dari Sumarmo (2013). Data kemampuan pemecahan masalah matematis siswa diolah dengan deskriptif kualitatif serta uji Mann-Whitney karena data n-gain kelas Accelerated learning tidak berdistribusi normal.. Pengolahan data dilakukan melalui pengunaan SPSS for windows dengan taraf signifikansi $\alpha=0,05$.

Tabel 2. Kemampuan Pemecahan Masalah Matematis

\begin{tabular}{ccccccc}
\hline Data & \multicolumn{3}{c}{ Accelerated Learning } & \multicolumn{3}{c}{ Ekspositori } \\
\cline { 2 - 7 } & Pretes & Postes & N-Gain & Pretes & Postes & N-Gain \\
$\overline{\mathbf{x}}$ & 5,82 & 16,97 & 0,51 & 5,09 & 13,39 & 0,37 \\
SD & 2,57 & 5,00 & 0,71 & 2,50 & 3,35 & 0,13 \\
$N$ & 33 & 33 & 33 & 33 & 33 & 33 \\
\hline
\end{tabular}


Tabel 2 memperlihatkan hasil rata-rata skor kemampuan pemecahan masalah matematis siswa meningkat setelah mendapat pembelajaran baik accelerated learning dan pembelajaran ekspositori. Peningkatan rata-rata skor kemampuan pemecahan masalah matematis siswa yang mendapat pembelajaran accelerated learning lebih tinggi daripada siswa yang memperoleh pembelajaran ekspositori. Jika sebelum mendapat accelerated learning skor rata-rata kemampuan pemecahan masalah matematis siswa hanya 5,82. Setelah mendapat pembelajaran accelerated learning,skor rata-rata kemampuan pemecahan masalah matematis siswa menjadi 16,97 meningkat 0,51. Sedangkan skor rata-rata kemampuan pemecahan masalah matematis siswa dengan pembelajaran ekspositori hanya meningkat sebesar 0,37 yaitu dari 5,09 menjadi 13,39. Skor peningkatan kemampuan pemecahan masalah matematis siswa pada kedua kelas berada pada kategori sedang.

Untuk mengetahui apakah peningkatan kemampuan pemecahan masalah matematis siswa yang mendapat pembelajaran accelerated learning lebih tinggi secara signifikan dibandingkan kelas ekspositori maka digunaka uji Mann-Whitney karena skor rata-rata $n$-gain pada kelas yang mendapatkan pembelajaran accelerated learning tidak berdistribusi normal. Pengujian beda rata-rata $n$-gain kemampuan pemecahan masalah matematis ini dilakukan untuk menjawab hipotesis "Peningkatan kemampuan pemecahan masalah matematis siswa dengan pembelajaran accelerated learning lebih tinggi secara signifikan daripada siswa yang memperoleh pembelajaran ekspositori”. Hasil uji perbedaan rata-rata $n$-gain kemampuan pemecahan masalah matematis siswa tersebut disajikan di Tabel 3.

Tabel 3. Daftar Uji Perbedaan Dua Rata-rata Skor N-Gain

\begin{tabular}{cccc}
\hline & Kelas & Mann-Whitney & $\begin{array}{c}\text { Asymp.Sig. } \\
\text { (2-tailed) }\end{array}$ \\
\hline N-Gain & $\begin{array}{c}\text { Accelerated } \\
\text { Learning } \\
\text { Ekspositori }\end{array}$ & 306,000 & 0,002 \\
\hline
\end{tabular}

Dari Tabel 3 menunjukkan nilai sig. (2-tailed) yaitu 0,002. Setengah dari nilai sig. ini, $\frac{1}{2}(0,002)=0,001$ kurang dari $\alpha=0,05$, maka berdasarkan kriteria pengujian di atas, $\mathrm{H}_{0}$ ditolak. Hal ini berarti bahwa rata-rata peningkatan kemampuan pemecahan masalah matematis siswa yang memperoleh pembelajaran dengan metode accelerated learning lebih tinggi secara signifikan daripada siswa yang memperoleh pembelajaran ekspositori. 
Pembelajaran matematika dengan accelerated learning ke enam langkah yaitu mind, acquire, search-out, trigger, exhibit dan refleksi memberikan lebih banyak kesempatan kepada siswa agar meningkatkan kemampuan pemecahan masalah matematisnya daripada pembelajaran ekspositori. Pada langkah mind siswa diberikan motivasi untuk belajar melalui pengenalan tokoh ilmuwan matematika seperti phytagoras, siswa diberitahukan manfaat apa yang diperoleh setelah belajar materi tersebut. Siswa melakukan games yang berhubungan dengan materi yang sedang dipelajari akan membuat pembelajaran lebih menyenangkan sehingga meningkatkan motivasi siswa untuk belajar.

Siswa mendapat informasi yang mendasar guna mendorong siswa untuk mengkontruksi pengetahuannya sendiri terjadi pada langkah acquire (Hutagaol, 2009: 2). Pemberian soal non-rutin yang diselesaikan secara kelompok pada langkah search-out melatih siswa untuk melakukan pemecahan masalah . Peningkatan kemampuan pemecahan masalah matematis siswa terjadi karena adanya diskusi dengan siswa lain dalam kelompoknya. Siswa mempresentasikan hasil kerja kelompoknya terjadi pada langkah exhibit. Pada langkah exhibit, kelompok diberikan kesempatan untuk bertanya dan evaluasi hasil pemikiran kelompok lain (Gokhale, 1995). Siswa melakukan evaluasi cara belajar dan hasil belajar serta merencanakan cara belajar yang lebih tepat guna meningkatkan kemampuan belajarnya dilakukan pada langkah refleksi.

\section{KESIMPULAN}

Berdasarkan uraian di atas ditarik kesimpulan yakni peningkatan kemampuan pemecahan masalah matematis siswa yang memperoleh pembelajaran accelerated learning lebih tinggi secara signifikan dibandingkan siswa yang mendapat pembelajaran ekspositori. Kemampuan pemecahan masalah matematis siswa meningkat karena dalam pembelajaran accelerated learning siswa belajar aktif, mengkontruksi pengetahuannya sendiri, melakukan pemecahan masalah secara berkelompok, mempresentasikan hasil pekerjaan kelompok dan melakukan evaluasi terhadap cara belajarnya.

\section{REKOMENDASI}

Pembelajaran accelerated learning dapat menjadi salah satu pilihan metode pembelajaran yang dapat digunakan dalam pembelajaran matematika untuk meningkatkan kemampuan pemecahan masalah matematis siswa. Lebih lanjut, dapat dilakukan penelitian 
dengan menggunakan pembelajaran accelerated learning dengan subjek penelitiannya siswa SMA untuk meningkatkan kemampuan pemecahan masalah matematis maupun kemampuan matematis yang lain.

\section{UCAPAN TERIMAKASIH}

Bagian ucapan terimakasih berisi ucapan terima kasih kepada pihak-pihak (jika ada) yang telah membantu dalam kegiatan penelitian yang dilakukan. Pihak-pihak tersebut, misalnya penyandang dana penelitian, pakar yang berkontribusi dalam diskusi atau pengolah data yang terkait langsung dengan penelitian/penulisan.

\section{REFERENSI}

Branca, N. A. (1980). Problem Solving as A Goal, Process and Basic Skill. Dalam Kruklik, S dan Reys, R.E. (Ed). Problem Solving in School Mathematisc. Reston, VA: NCTM.

De Porter, B. \& Hernacki, M. (1999). Quantum Learning : Membiasakan Belajar Nyaman dan Menyenangkan. Terjemahan Ary Nilandri. Bandung: Kaifa.

Hake, R. R. (1999). Analizing Change/Gain Scores. [Online]. Tersedia: http://www.physics.indiana.edu/ sdi/AnalyzingChange-Gain.pdf [12 Desember 2013]

Hutagaol, K. (2009). Strategi Multi Representasi dalam Kelompok Kecil untuk Meningkatkan Kemampuan Pemecahan Masalah dan Kemampuan Komunikasi Matematis Siswa Sekolah Menengah Pertama. Disertasi pada SPs UPI Bandung: Tidak diterbitkan.

Polya. (1985). How to Solve It. A New Aspect of Mathematical Method. Second Edition. New Jersey: Princeton University Press.

Putra, D. (2012). Penerapan Accelerated Learning dalam Peningkatan Kemampuan Penalaran dan Komunikasi Matematis Siswa Sekolah Menengah Pertama. Tesis pada PPs UPI Bandung: Tidak diterbitkan.

Rose, C. \& Nicholl, M. J. (2002). Accelerated Learning for The $21^{\text {st }}$ Century Cara Belajar Cepat Abad XXI. Nuansa: Bandung.

Ruseffendi, E. T. (2005). Dasar-dasar Penelitian Pendidikan dan Bidang Non Eksakta Lainnya. Bandung: Tarsito. 
45 SUPERMAT, Volume 3, No. 2, November 2019, hal. 38-45

Sumarmo, U. (2013). Kumpulan Makalah Berpikir dan Disposisi Matematik serta Pembelajaran. Jurusan Pendidikan Matematika-Fakultas Pendidikan Matematika dan Ilmu Pengetahuan Alam-Universitas Pendidian Indonesia.

Suryadi, D. (2005). Penggunaan Pendekatan Pembelajaran Tidak Langsung serta Pendekatan Gabungan Langsung dan Tidak Langsung dalam Rangka Meningkatkan Kemampuan Berpikir Matematik Tingkat Tinggi Siswa SLTP. Disertasi pada PPS UPI Bandung: Tidak diterbitkan. 